\title{
Isolation and Partial Characterization of Infectious Molecular Clones of Feline Immunodeficiency Virus Obtained Directly from Bone Marrow DNA of a Naturally Infected Cat
}

\author{
KEES H. J. SIEBELINK, ${ }^{1}$ I-HAI CHU ${ }^{1}$ GUUS F. RIMMELZWAAN, ${ }^{1}$ KEES WEIJER, ${ }^{2}$ \\ ALBERT D. M. E. OSTERHAUS, ${ }^{1 *}$ AND MARNIX L. BOSCH ${ }^{1}$ \\ Laboratory of Immunobiology, National Institute of Public Health and Environmental Protection, Antonie van \\ Leeuwenhoeklaan 9, P.O. Box 1, 3720 BA Bilthoven, ${ }^{1}$ and Division of Immunology, The Netherlands Cancer Institute, \\ 1066 CX Amsterdam, ${ }^{2}$ The Netherlands
}

Received 19 June 1991/Accepted 25 October 1991

\begin{abstract}
Replication-competent molecular clones of feline immunodeficiency virus (FIV) were isolated directly from the DNA of bone marrow cells of a naturally FIV-infected cat. After transfection in a feline kidney cell line (CrFK) and subsequent cocultivation with peripheral blood mononuclear cells (PBMC), the viral progeny of the clones was infectious for PBMC but not for CrFK cells. PBMC infected with these clones showed syncytium formation, a decrease in cell viability, and gradual loss of $\mathrm{CD4}^{+}$cells. The restriction maps of these clones differed from those obtained for previously described molecular clones of FIV derived from cats in the United States. The predicted amino acid sequence similarity of the envelope genes of the two clones was 99.3\%, whereas the similarities of the sequences of the clones to those of two molecular clones from the United States, Petaluma and PPR, were 86 and $88 \%$, respectively. Most of the differences between the amino acid sequences of the two clones and those of the clones from the United States were found in five different hypervariable (HV) regions, HV-1 through HV-5. The viral progeny of one of these clones was inoculated into two specificpathogen-free cats. The animals seroconverted, and the virus could be reisolated from their PBMC.
\end{abstract}

Feline immunodeficiency virus (FIV) is a T-lymphotropic lentivirus initially isolated from an immunodeficient cat (23). FIV infection in cats can lead to immunological abnormalities similar to those seen in human immunodeficiency virus type 1 (HIV-1) infected humans, like a depletion of CD4 ${ }^{+}$ cells in circulation $(2,3,31)$. Similarly, the peripheral blood mononuclear cells (PBMC) from FIV-infected cats show reduced proliferative responses to mitogens and to exogenous interleukin 2 (IL-2) in vitro $(3,13,28)$. These similarities in biological behavior between HIV-1 and FIV may make FIV infection of cats a suitable small-animal system to study lentivirus pathogenesis as a model for human AIDS and may likewise identify the FIV system as a model for HIV vaccine development.

Lentiviruses display a large degree of molecular and biological variation. This variation is generally ascribed to the low fidelity of the viral enzyme reverse transcriptase (RT) in copying the viral genomic RNA to DNA $(25,26)$. The use of complete molecular clones allows one to obtain genomically homogeneous viral populations. Relating the biological properties of such populations to the genomic structure of the molecular clone from which they were derived may reveal the molecular basis of biological variation and may identify determinants of viral virulence. To date, molecular clones of three FIV strains have been described, two from the United States (the 34TF10 clone of the Petaluma strain $[22,30]$ and the PPR clone of the San Diego strain [24] and one from Japan (JM1 [21]), which were all obtained from the DNA of in vitro-propagated cells. Culturing in vitro may select for certain virus subpopulations and can induce new features in the propagated virus. Culturing of simian immunodeficiency virus (SIV) in human

\footnotetext{
* Corresponding author.
}

cells, e.g., can lead to the introduction of a premature termination codon in the viral transmembrane glycoprotein $(14,17)$. These problems make the availability of complete molecular clones obtained directly from the DNA of in vivo-infected cells highly desirable. Here we report on two replication-competent molecular clones derived directly from the DNA of bone marrow cells from an FIV-infected cat. The genomic structures of these clones and their presumed envelope gene sequences are presented.

HIV-1, HIV-2, and SIV infect cells via the CD4 molecule, which acts as the cellular receptor for these viruses $(8,15$, $18,19)$. These viruses are also cytopathic for $\mathrm{CD}^{+}$cells in vitro, and this cytopathic effect may at least in part underlie the virally induced immunodeficiency characterized by $\mathrm{CD}^{+}{ }^{+}$cell depletion in vivo. The CD4 analog in cats has been identified recently (1), but its role in FIV binding and entry is not yet clear. FIV infection also results in a reduction of $\mathrm{CD}^{+}$cells in circulation in infected cats. We have therefore investigated whether the molecular clones of FIV described here are cytopathic for $\mathrm{CD}^{+}$cells in vitro.

\section{MATERIALS AND METHODS}

Cells and virus. Bone marrow cells were obtained from the femur of a 4-year-old naturally FIV-infected free-roaming cat (Amsterdam-19) suffering from a generally debilitating disease and intermittent disease symptoms, including respiratory infections and chronic diarrhea, all suggestive of an immunodeficiency syndrome $(23,32)$. The cells were washed twice and used for isolation of genomic DNA (see below).

PBMC were isolated from heparinized blood from the cat by Ficoll density gradient centrifugation. The PBMC were washed three times with RPMI 1640 (GIBCO), supplemented with penicillin $(100 \mathrm{IU} / \mathrm{ml})$, streptomycin $(100 \mu \mathrm{g} /$ $\mathrm{ml})$, L-glutamine $(2 \mathrm{mM})$, and $\beta$-mercaptoethanol $\left(2 \times 10^{-5}\right.$ 
M), designated culture medium (CM). A total of $10^{7}$ PBMC were stimulated with $5 \mu \mathrm{g}$ of concanavalin A (ConA) (Flow Laboratories, Inc.) per $\mathrm{ml}$ in CM supplemented with $10 \%$ heat-inactivated fetal calf serum (FCS). After 3 days, the cells were washed once and further cultured with $\mathrm{CM}$ supplemented with $10 \%$ FCS and IL-2 (100 IU/ml) (Cetus). The culture supernatant was monitored weekly for the presence of FIV antigen in an FIV antigen capture enzymelinked immunosorbent assay (ELISA) as described previously (29). A virus stock of FIV from cat Amsterdam-19 (designated FIV Amsterdam-19) was made from the supernatant of this culture 21 days after stimulation and stored in aliquots at $-135^{\circ} \mathrm{C}$. The RT activity was assayed and was 7.0 $\times 10^{4} \mathrm{cpm} / \mathrm{ml}$.

PBMC were derived from heparinized blood of a specificpathogen-free (SPF) cat by Ficoll density gradient centrifugation. The cells were washed twice and frozen at $-135^{\circ} \mathrm{C}$ in aliquots in CM supplemented with $10 \% \mathrm{FCS}$ and $10 \%$ dimethyl sulfoxide. Before use, the cells were thawed and stimulated with ConA $(5 \mu \mathrm{g} / \mathrm{ml})$ for 3 days and further cultured with IL-2 $(100 \mathrm{IU} / \mathrm{ml})$.

An FIV-susceptible clone of the Crandell feline kidney cell line ( $\mathrm{CrFK}$ ) was obtained from N. Pedersen (32). The cells were cultured in Dulbecco's modified Eagle's medium supplemented with penicillin $(100 \mathrm{IU} / \mathrm{ml})$, streptomycin $(100$ $\mu \mathrm{g} / \mathrm{ml})$, L-glutamine $(2 \mathrm{mM}), \beta$-mercaptoethanol $\left(2 \times 10^{-5}\right.$ $\mathrm{M})$, and $10 \%$ FCS.

DNA isolation. Genomic DNA was isolated from bone marrow cells. A total of $10^{8}$ bone marrow cells of cat Amsterdam-19 were washed twice and lysed with $100 \mu \mathrm{g}$ of proteinase $\mathrm{K}$ per $\mathrm{ml}$ and $0.5 \%$ sodium dodecyl sulfate (SDS) for $16 \mathrm{~h}$ at $42^{\circ} \mathrm{C}$. Cesium chloride $(1.25 \mathrm{~g} / \mathrm{ml}$ of lysate) was added, and after centrifugation for $44 \mathrm{~h}$ at $60,000 \mathrm{rpm}$ in a 70 Ti rotor (Beckman), fractions containing the high-molecularweight DNA were collected, pooled, and dialyzed against TE (10 mM Tris, pH 8.0, and 0.1 mM EDTA).

Southern blot analysis of genomic DNA. Genomic DNA was digested with BamHI or NheI. After electrophoresis, the DNA was transferred to nitrocellulose and hybridized with the ${ }^{32} \mathrm{P}$-labeled gag probe $\mathrm{P}_{2}$ (see below) in hybridization buffer $(3 \times \mathrm{SSC}$ [ $1 \times \mathrm{SSC}$ is $0.15 \mathrm{M} \mathrm{NaCl}$ plus $0.015 \mathrm{M}$ sodium citrate], $50 \mathrm{mM}$ Tris, $5 \times$ Denhardt's solution, $0.5 \%$ SDS, $5 \mathrm{mM}$ EDTA, $50 \%$ formamide, $10 \%$ dextran sulfate, and $10 \mu \mathrm{g}$ of salmon sperm DNA per $\mathrm{ml}$ ). The blots were washed twice with $0.2 \times \mathrm{SSC}-0.1 \%$ SDS for $30 \mathrm{~min}$ at $68^{\circ} \mathrm{C}$ each time and autoradiographed.

Molecular cloning of FIV proviral DNA. Genomic DNA from bone marrow cells from cat Amsterdam-19 was partially digested with $\mathrm{Sau} 3 \mathrm{~A}$. After size fractionation on a 5 to $25 \% \mathrm{NaCl}$ gradient, 10 - to 20 -kb fragments were ligated to EMBL-3 lambda arms (Stratagene) and packaged in vitro. The unamplified lambda phage library was screened with the probes $\mathrm{P}_{2}$ (1.8-kb Sst I-Bam HI gag fragment) and $\mathrm{P}_{22}(2.1-\mathrm{kb}$ BamHI-BamHI pol fragment), which were obtained from R. Olmsted (22), and ENV-4 (a 2.6-kb fragment spanning the complete envelope gene obtained by polymerase chain reaction [25a]).

Positive plaques were purified, and the DNA was isolated. SphI-SalI fragments of these clones were subcloned in pUC19. The subclones were used for the dideoxynucleotide chain termination sequence reaction (27) of the env gene. The nucleotide and protein alignments as well as the percentages of similarity were determined with Lasergene software (DNAstar Inc., London, United Kingdom).

Purified lambda DNA was used for the construction of a restriction enzyme map. Lambda DNA from the clones was digested with the restriction enzymes $B a m H I, B g l I I, E c o R I$, KpnI, NheI, SphI, and SstI and, after electrophoresis on a $0.8 \%$ agarose gel, transferred to nitrocellulose. The filters were subsequently hybridized with $\mathrm{P}_{2}, \mathrm{P}_{22}$, or ENV-4 and autoradiographed.

DNA transfection. A sample of $5 \mu \mathrm{g}$ of lambda DNA was transfected into CrFK cells by using the cationic lipid DOTMA (lipofectin; Bethesda Research Laboratories, Inc.) according to the protocol of the manufacturer. Briefly, $5 \mu \mathrm{g}$ of DNA in $50 \mu \mathrm{l}$ of $\mathrm{H}_{2} \mathrm{O}$ was mixed with $50 \mu \mathrm{l}$ of lipofectin and incubated for $15 \mathrm{~min}$ at room temperature. CrFK cells were washed with serum-free Dulbecco's modified Eagle's medium, and the lipofectin reagent-DNA complex was added. Twenty-four hours after transfection, CM containing $20 \%$ FCS, 100 IU of IL-2 per ml, and $5 \times 10^{6}$ ConA- and IL-2-stimulated PBMC from an SPF cat were added. After $72 \mathrm{~h}$, the PBMC and CrFK cells were washed and cultured separately. The culture supernatant was monitored for the presence of FIV antigen in an FIV antigen capture ELISA. Eighteen days after transfection, a virus stock was made and stored in aliquots at $-135^{\circ} \mathrm{C}$. The RT activity was determined. The infected cells were used for electron microscopy essentially as described by Gelderblom et al. (11).

Infection of PBMC. ConA- and IL-2-stimulated PBMC of an SPF cat were infected with the molecular clones or with the biological isolate FIV Amsterdam-19 by resuspending $10^{7} \mathrm{PBMC}$ in $1 \mathrm{ml}$ of virus dilution in CM containing $2 \times 10^{4}$ cpm of RT activity per ml. After $1 \mathrm{~h}$ at $37^{\circ} \mathrm{C}$, the cells were washed twice with $\mathrm{CM}$ and cultured in $\mathrm{CM}$ supplemented with $10 \%$ FCS and 100 IU of IL-2 per ml. Twice a week, 1.5 $\mathrm{ml}$ of culture supernatant was centrifuged $(10 \mathrm{~min}$ at $300 \times \mathrm{g})$ and stored at $-135^{\circ} \mathrm{C}$ until testing for the presence of FIV antigen and RT activity. The cells were monitored for cytopathic effects like syncytium formation and cell viability and for the percentages of $\mathrm{CD}^{+}$and $\mathrm{CD}^{+}$cells by fluorescence-activated cell sorter analysis with monoclonal antibodies provided by $\mathbf{M}$. Cooper $(1,16)$.

RT assay. RT activity was assayed in a microassay as previously described by Gregersen et al. (12), with minor variations. Briefly, $1 \mathrm{ml}$ of culture supernatant was precipitated with $0.25 \mathrm{ml}$ of $32 \%$ polyethyleneglycol $6000-1.5 \mathrm{M}$ $\mathrm{NaCl}$. The pellets were resuspended in $10 \mu \mathrm{l}$ of lysis buffer (50 mM Tris [pH 8.3], $20 \mathrm{mM}$ dithiothreitol, $0.25 \%$ Triton X-100) and mixed with $40 \mu \mathrm{l}$ of $\mathrm{H}_{2} \mathrm{O}$ and $50 \mu \mathrm{l}$ of RT cocktail (100 mM Tris [pH 7.9], $150 \mathrm{mM} \mathrm{KCl,} 10 \mathrm{mM} \mathrm{MgCl}, 4 \mathrm{mM}$ dithiothreitol, $0.6 \mathrm{U}$ of poly(rA) - oligo(dT), $60 \mu \mathrm{Ci}$ of $\left[{ }^{3} \mathrm{H}\right]$ TTP per ml). After incubation at $37^{\circ} \mathrm{C}$ for $1 \mathrm{~h}$, the DNA was precipitated with $20 \mu \mathrm{l}$ of $120 \mathrm{mM} \mathrm{Na} \mathrm{P}_{2} \mathrm{O}_{7} \cdot 10 \mathrm{H}_{2} \mathrm{O}$ in $60 \%$ trichloroacetic acid for $15 \mathrm{~min}$ at $4^{\circ} \mathrm{C}$. The DNA was spotted onto glass fiber filters with a Skatron cell harvester and washed with $12 \mathrm{mM}$ PPNa in $5 \%$ trichloroacetic acid. The filters were dried, and $\left[{ }^{3} \mathrm{H}\right] \mathrm{TTP}$ incorporation was measured in a $\beta$-scintillation counter.

Nucleotide sequence accession number. The sequences reported in this paper have been deposited in the GenBank data base (accession no. for clone 19k1 is M73964 and for clone $19 \mathrm{k} 32$ is M73965).

\section{RESULTS}

Molecular cloning and characterization of FIV provirus. Genomic DNA from bone marrow cells of a naturally FIV-infected free-roaming cat (Amsterdam-19) was digested with restriction enzymes and blotted onto nitrocellulose for hybridization with probe $\mathrm{P}_{2}$, FIV-specific DNA could be detected in this DNA preparation as well as in the DNA 


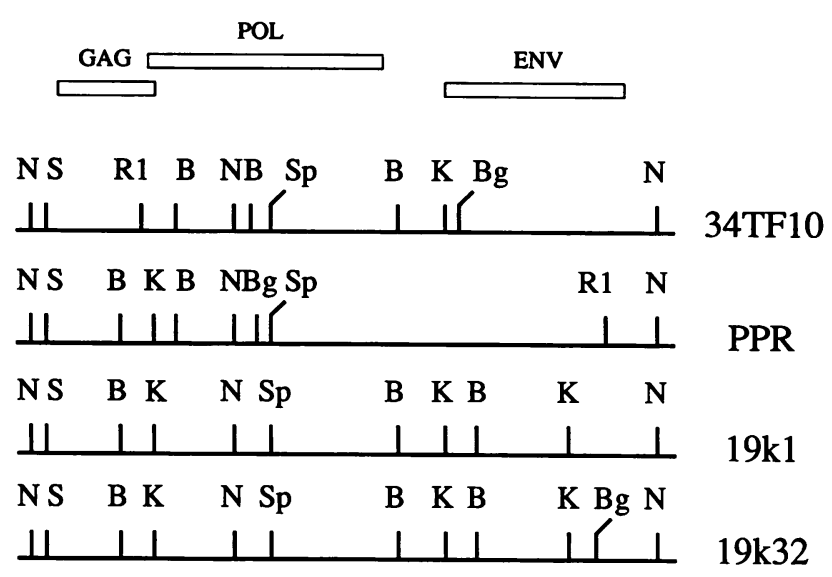

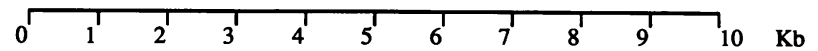

FIG. 1. Restriction map of infectious molecular clones of FIV strains Petaluma (34TF10), San Diego (PPR), and FIV Amsterdam-19 (19k1 and 19k32). Restriction enzyme maps of 34TF10 and PPR are as predicted from their published nucleotide sequences (24, 30). Maps of $19 \mathrm{k} 1$ and $19 \mathrm{k} 32$ were obtained by single and double restriction enzyme digestion of lambda DNAs which contain the full-length clones, followed by Southern blotting and hybridization with the ${ }^{32} \mathrm{P}$-labeled FIV-specific probes $\mathrm{P}_{2}, \mathrm{P}_{22}$, or ENV-4. Restriction enzyme cleaving sites: B, BamHI; Bg, BglII; R1, EcoRI; K, KpnI; N, Nhel; Sp, SphI; and S, SstI.

obtained from the spleen cells of cat Amsterdam-19 and the spleen and bone marrow cells of another naturally FIVinfected cat (data not shown). Digestion with BamHI or NheI yielded internal FIV fragments with sizes of 3.8 and 3.2 $\mathrm{kb}$, respectively. These fragments are also found in the maps of lambda clones $19 \mathrm{k} 1$ and $19 \mathrm{k} 32$ (see below).

Full-length proviral FIV clones were obtained from an EMBL-3 lambda phage library made directly from the DNA of the bone marrow cells of cat Amsterdam-19 by using the $\mathrm{P}_{2}, \mathrm{P}_{22}$, and ENV-4 probes for screening. The hybridizing clones were plaque purified and used for the isolation of lambda DNA. The replication competence of the cloned FIV provirus was assayed by transfection into $\mathrm{CrFK}$ cells (see below). Three clones $(19 \mathrm{k} 1,19 \mathrm{k} 32$, and $19 \mathrm{k} 36)$ gave rise to FIV antigen production upon transfection and were characterized further. Restriction maps of these three clones showed a high degree of similarity (Fig. 1). The maps of clones $19 \mathrm{k} 1$ and $19 \mathrm{k} 36$ were identical, whereas an additional $B g l$ II site is present in the envelope gene of clone $19 \mathrm{k} 32$. This additional $B g l$ II site was later confirmed by sequence analysis. When the predicted maps of the two U.S. clones (24, 30) were compared with that of clone $19 \mathrm{k} 1$, only 14 of 22 (34TF10 compared with $19 \mathrm{k} 1$, respectively) and 14 of 21 (PPR compared with $19 \mathrm{k} 1$, respectively) restriction sites appeared to be conserved. Between 34TF10 and PPR, 12 of 21 restriction sites are conserved (Fig. 1). This indicates a high degree of heterogeneity among these different FIV strains.

We obtained the nucleotide sequences of the envelope genes of the three clones of FIV Amsterdam-19. The nucleotide sequences of the envelope genes and the preliminary restriction site analyses of the $5^{\prime}$ - and $3^{\prime}$-flanking sequences of clones $19 \mathrm{k} 1$ and $19 \mathrm{k} 36$ showed no differences, which suggests that these clones are fully identical. On the other hand, we found that clones $19 \mathrm{k} 1$ and $19 \mathrm{k} 32$ differed in the length of their flanking sequences (data not shown), and only the sequences of these clones were analyzed further. The 2,571 nucleotides of the envelope genes of these clones differ in only nine positions. Because of the lack of direct amino acid sequence data, it is as yet unclear where the exact initiation codon of the envelope gene is located. We have presumed the conserved ATG at position 6264 of clone $34 \mathrm{TF} 10$ of the Petaluma strain (30) to be the initiation codon for the env gene, which then encodes an 857-amino-acid glycoprotein with a potential cleavage site after 611 amino acids, resulting in a 611-amino-acid surface glycoprotein and a 246-amino-acid transmembrane glycoprotein. The predicted amino acid sequences of the envelope glycoproteins of these clones were compared with those of the 34TF10 clone of the Petaluma strain and the PPR clone of the San Diego strain $(24,30)$ (Fig. 2). The amino acid identity of the envelope glycoproteins of clones $19 \mathrm{k} 1$ and $19 \mathrm{k} 32$ is $99.3 \%$. The sequence identities of these two highly related clones with the 34TF10 and PPR clone envelope sequences are 86 and $84 \%$, respectively. We have aligned the four envelope gene sequences (Fig. 2). Although amino acid variation is found throughout the entire env gene, we observed the presence of five hypervariable (HV) regions, designated $\mathrm{HV}-1$ through $\mathrm{HV}-5$, as indicated in Fig. 2. These HV regions concur in part with the variable regions described by Phillips et al. (24). All four sequences are remarkably colinear, with insertions and/or deletions found only in HV-5 (Fig. 2). Most of the potential N-linked glycosylation sites are conserved between the envelope sequences of all four clones (21 of 22); some variation of the cysteine residues is observed within the first 150 amino acids.

Biological characterization. Lambda phage, containing apparently full-length proviral DNA of clones $19 \mathrm{k} 1,19 \mathrm{k} 32$, and 19k36, was transfected into CrFK cells. These were then cocultivated with PBMC for $72 \mathrm{~h}$. Both cell populations were then cultured separately. In the PBMC cultures infected with clones $19 \mathrm{k} 1$ and $19 \mathrm{k} 32$, FIV antigen could be detected within 8 days after transfection. FIV antigen was also detected in the PBMC culture of clone $19 \mathrm{k} 3612$ days after transfection. Transmission electron microscopy pictures from all of these cultures showed mature and immature virus particles and particles budding from the cell membrane (data not shown). FIV antigen could not be detected in the supernatant of the CrFK cell cultures. The PBMC cultures were expanded, and virus stocks were stored at $-135^{\circ} \mathrm{C}$. The RT activities of the stocks were $2.3 \times 10^{4}, 2.9 \times 10^{4}$, and $0.5 \times 10^{4} \mathrm{cpm} / \mathrm{ml}$ for $19 \mathrm{k} 1,19 \mathrm{k} 32$, and $19 \mathrm{k} 36$, respectively. On the basis of apparent genetic identity of $19 \mathrm{k} 1$ and $19 \mathrm{k} 36$ (see above), we have concentrated on clones $19 \mathrm{k} 1$ and $19 \mathrm{k} 32$ for further analysis.

ConA- and IL-2-stimulated PBMC $\left(10^{7}\right)$ from an SPF cat were infected with equal amounts of RT activity $\left(2 \times 10^{4}\right.$ $\mathrm{cpm}$ ) of the viral progeny of clone $19 \mathrm{k} 1$ or $19 \mathrm{k} 32$ or the biological isolate FIV Amsterdam-19 obtained from in vitropropagated PBMC. The cultures were monitored for syncytium formation, cell death, percent $\mathrm{CD}^{+}$and $\mathrm{CD}^{+}$cells, FIV antigen production, and RT activity. The results are shown in Fig. 3. Syncytium formation was seen 4 days postinfection (p.i.) in the culture infected with $19 \mathrm{k} 1$ and 6 days p.i. in the culture infected with $19 \mathrm{k} 32$ or the biological isolate (Fig. 4). FIV antigen and RT activity could be detected after $11(19 \mathrm{k} 1)$ and $14(19 \mathrm{k} 32$ and FIV Amsterdam19) days in the FIV-infected cultures but not in the noninfected control culture for 28 days p.i. (Fig. 3A and B).

The percent viable cells decreased from 95 to $55 \%$ during 28 days of culturing in the noninfected culture, whereas there was a more rapid decrease of viable cells in the 
HV-1

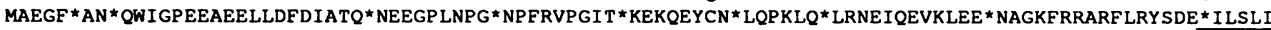

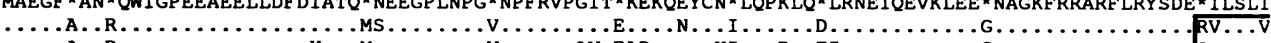

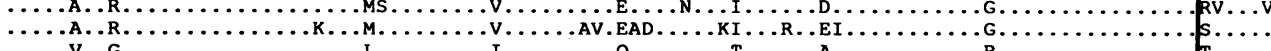
‥vv.

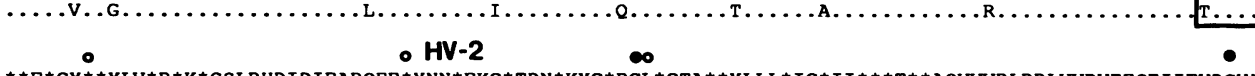

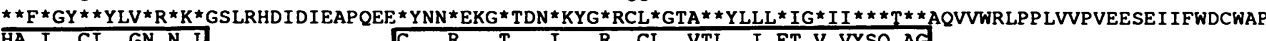

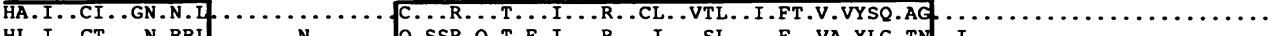

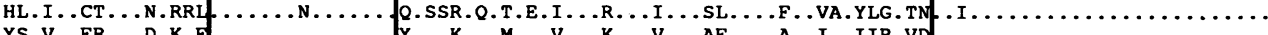

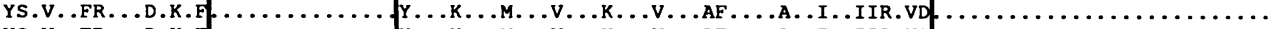

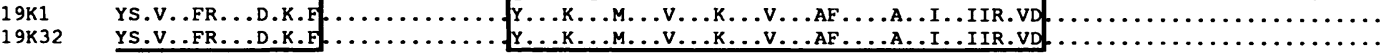

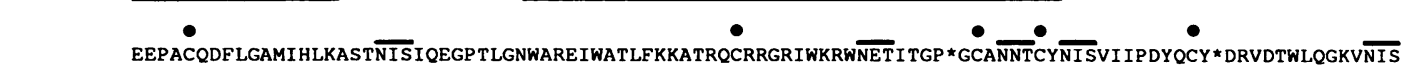

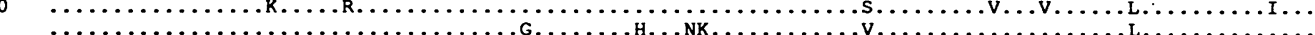
$19 \mathrm{~K} 1 \quad$. $19 K 32$ -

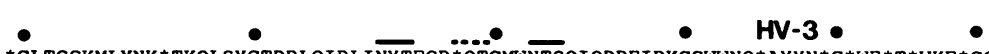

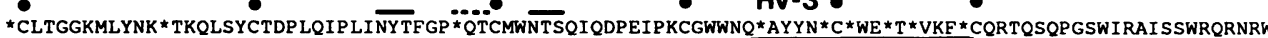

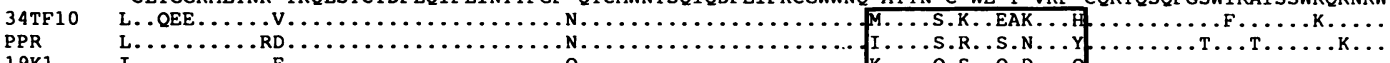

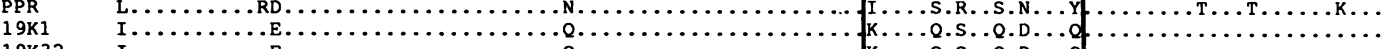

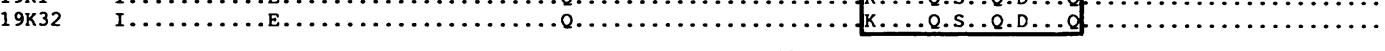

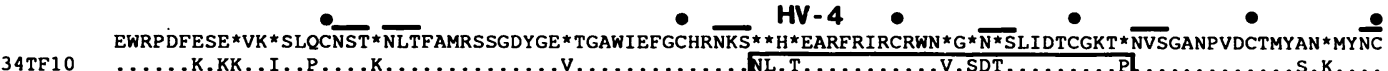

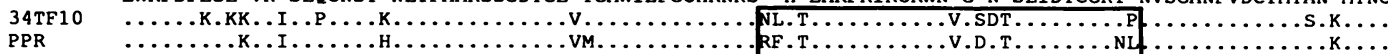
PPR
$19 \mathrm{~K} 1$$\quad$ …

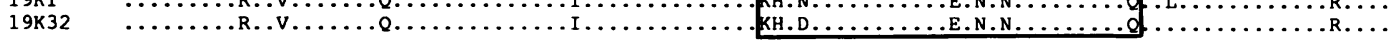

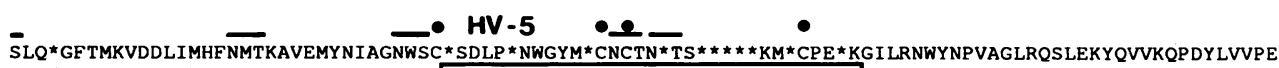

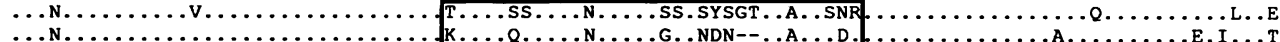

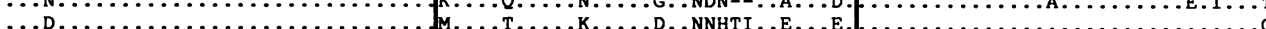

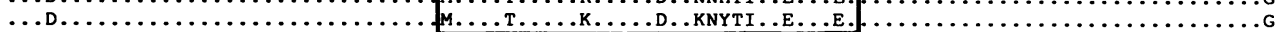

SU I TM

EVMEYKPRRKRAAI HVMLALATVLS *AGAGTGATAIGMVTQYHOVLATHOEAIEKVTEALKINNLRLVTLEHOVLVIGLKVEAIEKFLYTAFAMOELGCN

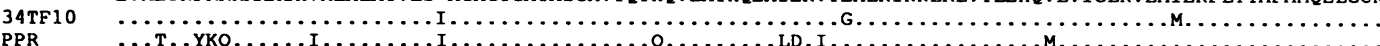

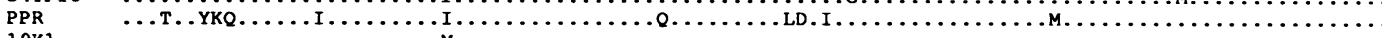

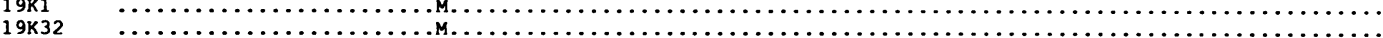

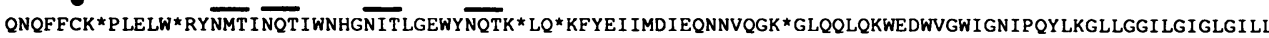

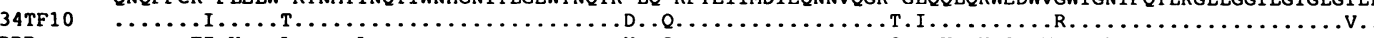

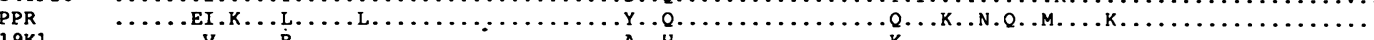

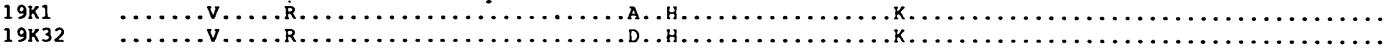

LILCLPTLVDCIRNCIHKILGYTVIAMP *VD*EEIQPQMELRRNGRQCGMSEKEEE

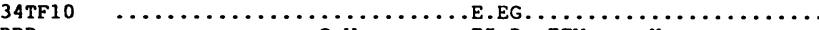

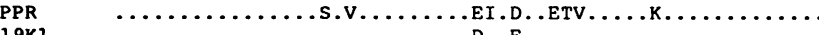

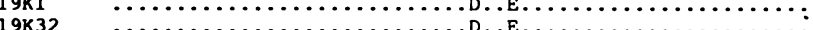

FIG. 2. Comparison of the predicted amino acid sequences of the envelope genes of molecular clones of the FIV strains Petaluma (34TF10), San Diego (PPR), and FIV Amsterdam-19 (19k1 and 19k32). HV regions (HV-1 through HV-5) are boxed. Solid lines, potential conserved glycosylation sites; dashed lines, nonconserved sites; closed circles, conserved cysteine residues; open circles, nonconserved residues. The presumed cleavage site between the surface glycoprotein (SU) and the transmembrane glycoprotein (TM) is also shown (see text for details).

FIV-infected cultures (only $15 \%$ viable cells after 28 days) (Fig. 3C), indicating cell death caused by FIV infection.

The percentages of the viable cells which were $\mathrm{CD}^{+}$and $\mathrm{CD}^{+}$cells could be measured accurately only during 18 days of culture following infection because of the low percent viable cells after this period. The percentages of viable cells which were $\mathrm{CD}^{+}$and $\mathrm{CD}^{+}$cells were 44 and $35 \%$, respectively, at the time of infection. After 18 days of culture, these percentages in the noninfected culture were 36 and $38 \%$, respectively. The mean percent $\mathrm{CD} 4^{+}$cells in all of the infected cultures decreased to $6 \%$ in 18 days p.i. The mean percent $\mathrm{CD}^{+}$cells increased to $66 \%$ in this period (data not shown), indicating a selective depletion of $\mathrm{CD}^{+}$ cells in infected cultures (Fig. 3D).

Two SPF cats were infected with the viral progeny of molecular clone $19 \mathrm{k} 1$, and two cats were infected with the biological isolate FIV Amsterdam-19. FIV could be isolated from these cats 2 weeks p.i., and seroconversion occurred 2 weeks later (data not shown). This demonstrates that these viruses are infectious in vivo.

\section{DISCUSSION}

We have generated molecular clones of FIV directly from the DNA of bone marrow cells of an FIV-infected cat and characterized these clones for genetic and biological properties. Cloning directly from in vivo-infected cells obviates the need for in vitro culturing of FIV in cell lines or in stimulated PBMC. In vitro culture systems may select some viral genotypes over others, as has been shown in numerous instances for HIV-1 $(7,9,20)$, or may even introduce modifications in the cultured virus as demonstrated for 

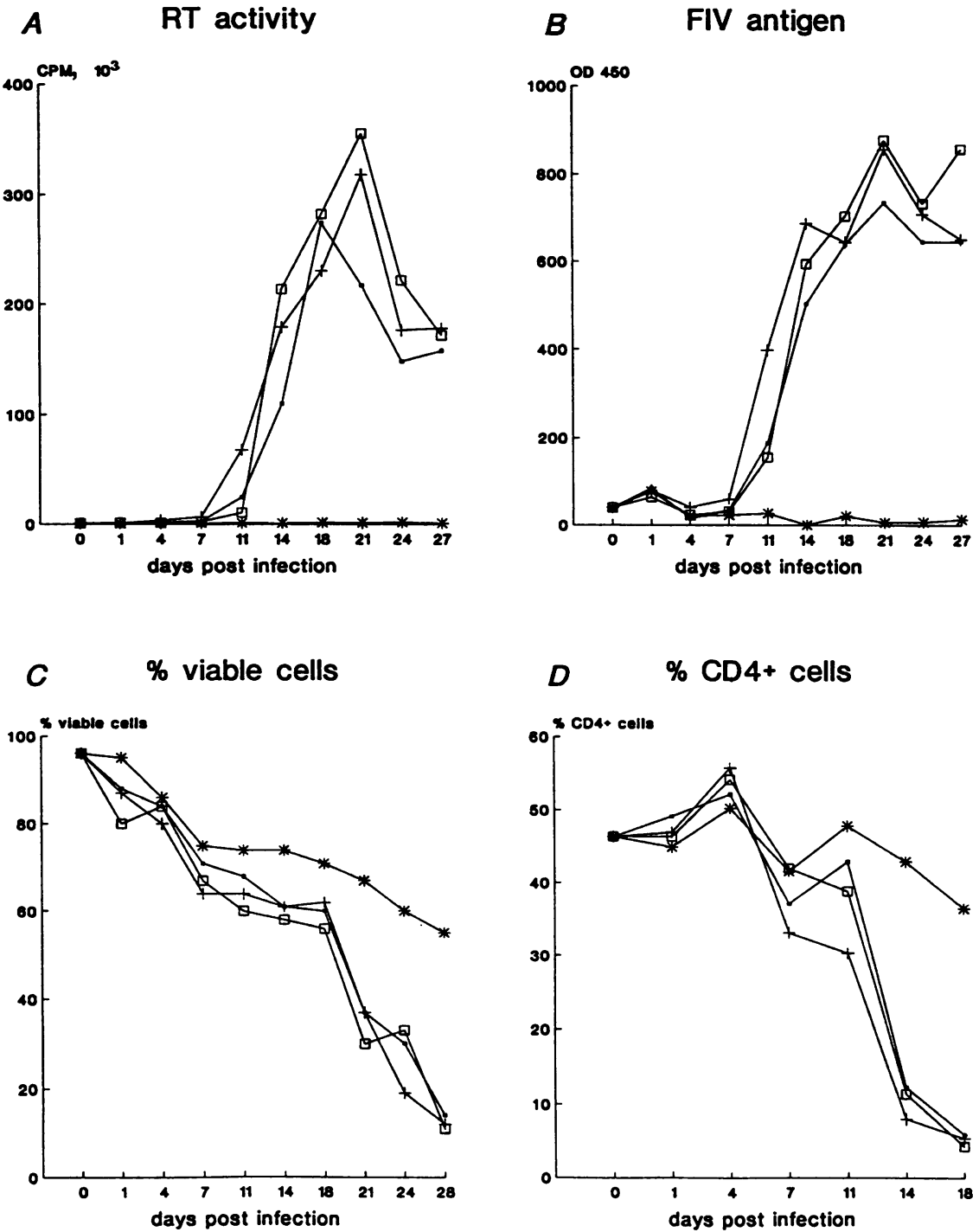

FIG. 3. Virus production, cell viability, and percent $\mathrm{CD}^{+}$cells in feline PBMC infected in vitro with FIV as described in the text. (A) RT activities in culture supernatant; (B) FIV antigen in culture supernatant; (C) percent viable cells; (D) percentages of viable cells which were CD4 ${ }^{+}$. Symbols: * , noninfected; $\square$, biological isolate FIV Amsterdam-19; $\bullet$, molecular clone 19k1; +, molecular clone $19 \mathrm{k} 32$.

$\operatorname{SIV}_{\text {mac }}(14,17)$. These drawbacks bring the inherent danger that a molecularly cloned virus obtained from in vitro cultures is not representative of the virus population present in the infected animal. The high load of FIV proviral DNA in the bone marrow cells of the naturally infected symptomatic cat Amsterdam-19 has allowed us to obtain complete molecular clones of FIV directly ex vivo. FIV-specific DNA could be detected in genomic DNA of bone marrow cells of cat Amsterdam-19 and in the DNA of bone marrow cells of only one of six other naturally infected cats. It is as yet unclear whether the detection of FIV proviral DNA in the genomic DNA of bone marrow cells of FIV-infected cats is a general feature. In this paper, we show that the viral progeny of these clones has biological properties very similar to the virus isolate obtained from the PBMC of cat Amsterdam-19.

FIV has been shown to cause a depletion of CD4-bearing cells in infected animals, as HIV-1 does in infected humans $(2,3,31)$. For HIV-1, this depletion may be partly explained by its selective tropism for and cytopathic effect on CD4 ${ }^{+}$ cells, which has been demonstrated in vivo. Additionally, HIV-1 can downregulate the CD4 receptor on infected cells $(5,6)$. Although the CD4 analog in cats has been identified, the results as to its functioning as the receptor for FIV have so far been inconclusive. We demonstrate here that an FIV isolate as well as two infectious molecular clones of FIV selectively deplete $\mathrm{CD}^{+}$cells from a culture of feline PBMC (Fig. 3D). The viruses als $\rho$ induce the formation of syncytia in these cultures, indicating that the observed $\mathrm{CD}^{+}$cell depletion could well be the result of direct cytopathic effects, although we cannot rule out that downregulation of CD4 also plays a role. The fact that these molecularly cloned viruses induce syncytium formation and deplete $\mathrm{CD} 4^{+}$cells in vitro may indicate that they do the same in vivo upon experimental infection. Such effects would result in a progression towards immunodeficiency. In preliminary experiments, the viral progeny of at least one of the two described clones (namely, 19k1) proved to be infectious in vivo. The experimentally infected animals will be monitored closely for 


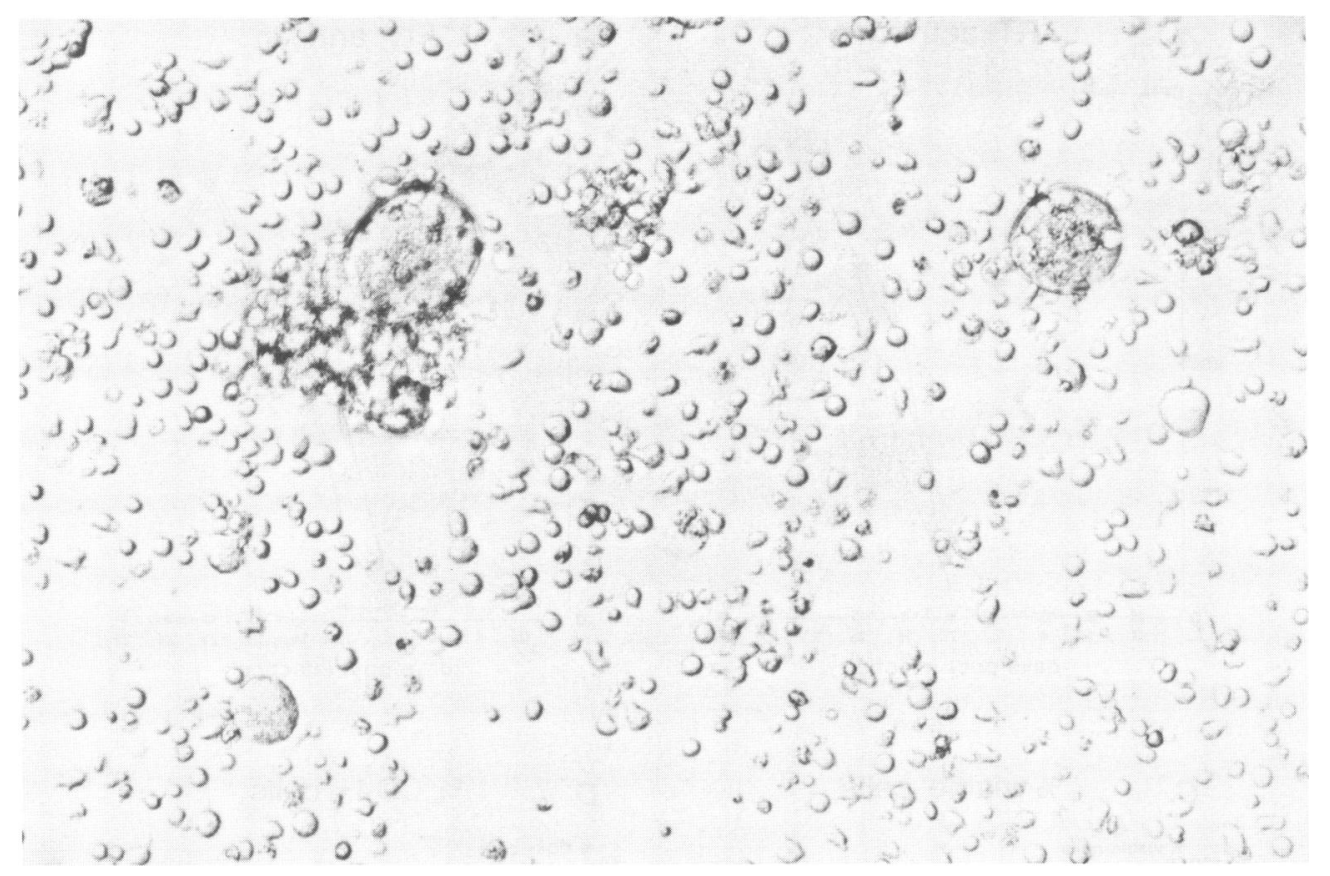

FIG. 4. Syncytium formation of feline PBMC which are infected with viral progeny of molecular clone $19 \mathrm{k} 1$ (magnification, $\times 400)$.

hematologic and immunologic parameters as well as for signs of FIV disease.

To facilitate transfection of the molecular clones, we have relied on an adherent cell line that is permissive for FIV replication, namely, the CrFK T-cell line. After transfection, the CrFK cells produced FIV particles whose viral progeny was thereupon rescued by cocultivation with feline PBMC. Interestingly, we could not show productive reinfection of CrFK cells by these viruses, indicating that one round of replication is not sufficient for the adaptation of FIV to CrFK cells. At the same time, these data demonstrate that the lack of growth of many FIV strains on CrFK cells is the result of a block at viral entry rather than at virus replication.

To date, two envelope sequences of FIV molecular clones have been obtained. The comparison of the sequences of these two U.S. isolates revealed an amino acid sequence similarity of approximately $85 \%$. To assess the amount of variation between strains from widely different geographical locations, we have obtained the complete envelope sequences of the molecular clones $19 \mathrm{k} 1$ and $19 \mathrm{k} 32$. These two sequences are remarkably similar (99.3\% similarity), whereas they differ by approximately $15 \%$ from both U.S. isolates, which is the amount of variation found between the U.S. isolates. A high degree of sequence similarity between two different proviruses is unusual for lentiviruses, which in general show much more sequence variation, especially in the envelope gene. The observed conservation may indicate that the obtained FIV clones are the progeny of the original viral clone that colonized the bone marrow of cat Amsterdam-19.

To predict the amino acid sequence of the envelope gene, we took the ATG at position 6264 of the 34 TF 10 clone of the Petaluma strain to be the start codon for env. This results in an 857-amino-acid glycoprotein with a potential cleavage site at position 611 (30). The precursor of the 857 amino acids can be cleaved into two smaller glycoproteins: an outer membrane protein of 611 amino acids and a transmembrane protein of 246 amino acids. The newly generated $\mathrm{N}$ terminus at the presumed transmembrane glycoprotein is highly hydrophobic and could serve as a fusion domain as demonstrated for the homologous regions in SIV $_{\text {mac }}$ and HIV-1 (4, 10). Although there is no obvious sequence similarity between this domain in FIV and those of SIV and HIV-1, we observed a high incidence of amino acids with very short side chains like glycine and alanine in all three viruses. This GA repeat may well be important for the function of the fusion domain. Most of the structurally important features of the envelope glycoproteins, like cysteine residues and $\mathrm{N}$-linked glycosylation sites, are conserved between these clones. Some nonconserved cysteine residues were found in the putative $\mathrm{L}$ gene region of the envelope glycoprotein, preceding the leader sequence identified by others $(24,30)$.

The molecular clones described in this report have been shown to be infectious both in vitro and in vivo. Such clones may enable us to delineate the molecular basis of the pathogenesis of FIV.

\section{ACKNOWLEDGMENTS}

We are grateful to R. Olmsted for kindly supplying us with the $P_{2}$ and $\mathrm{P}_{22} \mathrm{cDNA}$ probes, to $\mathrm{N}$. Pedersen for the CrFK cells, and to $\mathrm{M}$. Cooper for providing the CD4- and CD8-specific monoclonal antibodies. We acknowledge $\mathrm{K}$. Teppema and $\mathrm{M}$. Burger for performing the electron microscopy and J. Sonsma for performing the RT assay. We thank C. Kruyssen and M. Eskens for preparing the manuscript.

This work was supported by the Advisory Council on Health Research (RGO 88-90/89028) and the Concerted Action of the E.C. on Feline AIDS.

\section{REFERENCES}

1. Ackley, C. D., E. A. Hoover, and M. D. Cooper. 1990. Identification of a CD4 homologue in the cat. Tissue Antigens 35:92-98.

2. Ackley, C. D., J. K. Yamamoto, N. Levy, N. C. Pedersen, and M. D. Cooper. 1990. Immunologic abnormalities in pathogenfree cats experimentally infected with feline immunodeficiency virus. J. Virol. 64:5652-5655. 
3. Barlough, J. E., C. D. Ackley, J. W. George, N. Levy, R. Acevedo, P. F. Moore, B. A. Rideout, M. D. Cooper, and N. C. Pedersen. 1991. Acquired immune dysfunction in cats with experimentally induced feline immunodeficiency virus infection: comparison of short-term and long-term infections. J. Acquired Immune Defic. Syndr. 4:219-227.

4. Bosch, M. L., P. L. Earl, K. Fargnoli, S. Picciafuoco, F. Giombini, F. Wong-Staal, and G. Franchini. 1989. Identification of the fusion peptide of primate immunodeficiency viruses. Science 244:694-697.

5. Cheng-Mayer, C., M. Quiroga, J. W. Tung, D. Dina, and J. A. Levy. 1990. Viral determinants of human immunodeficiency virus type $1 \mathrm{~T}$-cell or macrophage tropism, cytopathogenicity, and CD4 antigen modulation. J. Virol. 64:4390-4398.

6. Crise, B., L. Buonocore, and J. K. Rose. 1990. CD4 is retained in the endoplasmic reticulum by the human immunodeficiency virus type 1 glycoprotein precursor. J. Virol. 64:5585-5593.

7. Dahl, K., K. Martin, and G. Miller. 1987. Differences among human immunodeficiency virus strains in their capacities to induce cytolysis or persistent infection of a lymphoblastoid cell line immortalized by Epstein-Barr virus. J. Virol. 61:1602-1608.

8. Dalgleish, A. C., P. C. L. Beverley, P. R. Clapham, D. H. Crawford, M. F. Greaves, and R. A. Weiss. 1984. The CD4 (T4) antigen is an essential component of the receptor for the AIDS retrovirus. Nature (London) 312:763-767.

9. Evans, L. A., T. M. McHugh, D. P. Stites, and J. A. Levy. 1987. Differential ability of human immunodeficiency virus isolates to productively infect human cells. J. Immunol. 138:3415-3418.

10. Freed, E. O., D. J. Myers, and R. Risser. 1990. Characterization of the fusion domain of the human immunodeficiency virus type 1 envelope glycoprotein gp41. Proc. Natl. Acad. Sci. USA 87:4650-4654.

11. Gelderblom, H. R., M. Özel, E. H. S. Hausmann, T. Winkel, G. Pauli, and M. A. Koch. 1988. Fine structure of human immunodeficiency virus (HIV), immunolocalization of structural proteins and virus-cell relation. Micron Microsc. Acta 19:41-60

12. Gregersen, J. P., H. Wege, L. Preiss, and K. D. Jentsch. 1988. Detection of human immunodeficiency virus and other retroviruses in cell culture supernatants by a reverse transcriptase microassay. J. Virol. Methods 19:161-168.

13. Hara, Y., T. Ishida, H. Ejima, M. Tagawa, S. Motoyoshi, I. Tomoda, M. Shimizu, and K. Shichinohe. 1990. Decrease in mitogen-induced lymphocyte proliferative responses in cats infected with feline immunodeficiency virus. Jpn. J. Vet. Sci. 52:573-579.

14. Hirsch, V. M., P. Edmondson, M. Murphey-Corb, B. Arbeille, P. R. Johnson, and J. I. Mullins. 1989. SIV adaption to human cells. Nature (London) 341:573-574.

15. Klatzman, D., E. Champagne, S. Chamaret, J. Gruest, D. Guetard, T. Hercend, J. Gluckman, and L. Montagnier. 1984. T-lymphocyte T4 molecule behaves as the receptor for human retrovirus LAV. Nature (London) 312:767-768.

16. Klotz, F. W., and M. D. Cooper. 1986. A feline thymocyte antigen defined by a monoclonal antibody (FT2) identifies a subpopulation of non-helper cells capable of specific cytotoxicity. J. Immunol. 136:2510-2514.

17. Kodama, T., D. P. Wooley, Y. M. Naidu, H. W. Kestler III, M. D. Daniel, Y. Li, and R. C. Desrosiers. 1989. Significance of premature stop codons in env of simian immunodeficiency virus. J. Virol. 63:4709-4714

18. Maddon, P. J., A. G. Dalgleish, J. S. McDougal, P. R. Clapman,
R. A. Weiss, and R. Axel. 1986. The T4 gene encodes the AIDS virus receptor and is expressed in the immune system and the brain. Cell 47:333-348.

19. McClure, M. O., Q. J. Sattenau, P. C. L. Beverley, J. P. Hearn, A. K. Fitzgerald, A. J. Zuckerman, and R. A. Weiss. 1987. HIV infection of primate lymphocytes and conservation of the CD4 receptor. Nature (London) 330:487-489.

20. Meyerhans, A., R. Cheynier, J. Albert, M. Seth, S. Kwok, J. Sninsky, L. Morfeldt-Manson, B. Asjö, and S. Wain-Hobson. 1989. Temporal fluctuations in HIV quasispecies in vivo are not reflected by sequential HIV isolations. Cell 58:901-910.

21. Miyazawa, T., M. Fukasawa, A. Hasegawa, N. Maki, K. Ikuta, E. Takahashi, M. Hayami, and T. Mikami. 1991. Molecular cloning of a novel isolate of feline immunodeficiency virus biologically and genetically different from the original U.S. isolate. J. Virol. 65:1572-1577.

22. Olmsted, R. A., A. K. Barnes, J. K. Yamamoto, V. M. Hirsch, R. H. Purcell, and P. R. Johnson. 1989. Molecular cloning of feline immunodeficiency virus. Proc. Natl. Acad. Sci. USA 86:2448-2452.

23. Pedersen, N. C., E. W. Ho, M. L. Brown, and J. K. Yamamoto. 1987. Isolation of a T-lymphotropic virus from domestic cats with an immunodeficiency-like syndrome. Science 235:790-793.

24. Phillips, T. R., R. L. Talbott, C. Lamont, S. Muir, K. Lovelace, and J. H. Elder. 1990. Comparison of two host cell range variants of feline immunodeficiency virus. J. Virol. 64:46054613.

25. Preston, B. D., B. J. Poiesz, and L. A. Loeb. 1988. Fidelity of HIV-1 reverse transcriptase. Science 242:1168-1171.

25a.Rimmelzwaan, G. Unpublished data.

26. Roberts, J. D., K. Bebenek, and T. A. Kunkel. 1988. The accuracy of reverse transcriptase from HIV-1. Science 242: 1171-1173.

27. Sanger, F. 1981. Determination of nucleotide sequences in DNA. Science 214:1205-1210.

28. Siebelink, K. H. J., I. Chu, G. F. Rimmelzwaan, K. Weijer, R. van Herwijnen, P. Knell, H. F. Egberink, M. L. Bosch, and A. D. M. E. Osterhaus. 1990 . Feline immunodeficiency virus (FIV) infection in the cat as a model for HIV infection in man: FIV-induced impairment of immune function. AIDS Res. Hum. Retroviruses 6:1373-1378.

29. Siebelink, C. H. J., R. W. Windrich, I. Chu, J. Groen, K. Weijer, F. G. C. M. UytdeHaag, and A. D. M. E. Osterhaus. 1989. An enzyme linked immunosorbent assay (ELISA) for the detection of feline immunodeficiency virus (FIV) antigen in cell culture and FIV specific antibodies in feline serum. Dev. Biol. Stand. 72:189-196.

30. Talbott, R. L., E. E. Sparger, K. M. Lovelace, W. M. Fitch, N. C. Pedersen, P. A. Luciw, and J. H. Elder. 1989. Nucleotide sequence and genomic organization of feline immunodeficiency virus. Proc. Natl. Acad. Sci. USA 86:5743-5747.

31. Torten, M., M. Franchini, J. E. Barlough, J. W. George, E. Mozes, H. Lutz, and N. C. Pedersen. 1991. Progressive immune dysfunction in cats experimentally infected with feline immunodeficiency virus. J. Virol. 65:2225-2230.

32. Yamamoto, J. K., E. Sparger, E. W. Ho, P. R. Andersen, T. P. O'Connor, C. P. Mandell, L. Lowenstine, R. Munn, and N. C. Pedersen. 1988. Pathogenesis of experimentally induced feline immunodeficiency virus infection in cats. Am. J. Vet. Res. 49:1246-1258. 